\section{Dilated cardiomyopathy in spider-monkey (Ateles chamek, Humboldt, 1812): case report}

\author{
Cardiomiopatia dilatada em macaco-aranha (Ateles chamek, \\ Humboldt, 1812): relato de caso
}

Heloisa Helena de Campos Coutinho Chaves ${ }^{1}$, Bárbara Souza Neil Magalhães ${ }^{2}$ (D) Andressa Kagohara ${ }^{3}$ (D), Fernando Troccoli' (1), Alessandro Oliveira Galhões ${ }^{1}$ (D), Mário dos Santos Filho ${ }^{4}$ (D),

Daniel de Almeida Balthazar ${ }^{5 *}$ (1) \& Jonimar Pereira Paiva ${ }^{5 t}$ (1)

'Veterinary, MSc. Independent scholar, Rio de Janeiro, RJ, Brasil

Veterinary, MSc. Laboratório de Sanidade Avícola, Faculdade de Veterinária, Universidade Federal Fluminense - UFF, Niterói, RJ, Brasil

${ }^{3}$ Veterinary. Independent scholar, Luanda, Angola

Veterinary, MSc, Doctoral Student. Programa de Pós-graduação em Medicina Veterinária - Ciências Clínicas, Universidade Federal Rural do Rio de Janeiro - UFRRJ, Seropédica, RJ, Brasil

${ }^{5}$ Veterinary, Dsc. Departamento de Medicina Veterinária e Cirurgia, Instituto de Veterinária, Universidade Federal Rural do Rio de Janeiro - UFRRJ, Seropédica, RJ, Brasil

${ }^{t}$ deceased

\begin{abstract}
Non-human primates are routinely studied and managed in zoos, conservation breeding centers, and research centers, but there is currently limited information regarding diseases that can affect these animals. Dilated cardiomyopathy is one of the most common cardiovascular diseases in small animal clinical practice. However, there are few reports of this condition occurring in non-human primates. Here, in a spider monkey (Ateles chamek) housed in the Rio de Janeiro Zoo, we report the occurrence of dilated cardiomyopathy, its etiology, pathophysiology, clinical presentation, diagnosis through clinical examination, and the use of complementary exams (radiographic, electrocardiographic, and echocardiographic), as well as the protocol, used in the treatment. In this case, it is assumed that the occurrence of the disease was related to the peripartum period due to the hormonal and metabolic changes that occurred, and the physiological interactions of gestation and puerperium.
\end{abstract}

Keywords: systolic dysfunction, non-human primates, treatment, neotropical primates.

\section{Resumo}

Primatas não humanos são constantemente estudados e manejados em parques zoológicos, criatórios conservacionistas e centros de pesquisa, porém há carência nas informações sobre enfermidades que podem acometer esses animais. A cardiomiopatia dilatada é uma das doenças cardiovasculares mais comuns na prática clínica de pequenos animais. No entanto há poucos relatos em primatas não humanos. O presente trabalho tem por objetivo relatar a ocorrência desta enfermidade em um exemplar de macaco-aranha (Ateles chamek) alojado no Jardim Zoológico da cidade do Rio de Janeiro, sua etiologia, fisiopatogenia, apresentação clínica, diagnóstico por meio do exame clínico e utilização de exames complementares (radiográfico, eletrocardiográfico e ecocardiográfico), bem como o protocolo utilizado no tratamento. No caso relatado pressupõe-se que a ocorrência da doença tenha sido relacionada com o período peri-parto devido às alterações hormonais e metabólicas ocorridas e ainda por interações fisiológicas da gestação e puerpério.

Palavras-chave: disfunção sistólica, primatas não-humanos, tratamento, primatas neotropicais.

\section{Introduction}

There are few records in the literature on diseases of the cardiovascular system in neotropical primates (Kindlovits \& Kindlovits, 2009). When compared to animals in situ, the maintenance of these apes in captivity influences their behavioral repertoire, increases their longevity, and consequently, the manifestation of diseases (Verona \& Pissinatti, 2014).

There are few reports of dilated cardiomyopathy (DCM) in primates, which is characterized by a reduction in myocardial contractility, a decrease in systolic myocardial function, and dilation of the left ventricle with or without arrhythmias (Lobo \& Pereira, 2002). The thickness of the walls

\section{BJ M \\ Brazilian Journal of Veterinary Medicine \\ p-ISSN 0100-2430 \\ e-ISSN 2527-2179 \\ ○}

How to cite: Chaves H.H.C.C., Magalhães B. S. N. Kagohara A., Troccoli F., Galhões A. O., Santos Filho M., Balthazar, D. A., \& Paiva, J. P. (2019) Dilated cardiomyopathy in spider-monkey (Ateles chamek, Humboldt, 1812): case report. Brazilian Journal of Veterinary Medicine, 41, e098219. https://doi.org/10.29374/2527-2179.bjvm098219

Financial support: The present work was carried out with the support of the Coordination of Improvement of Higher Education Personnel - Brazi (CAPES - Coordenação de Aperfeiçoamento de Pessoal de Nível Superior) - Financing Code 001.

Conflict of interests: No conflict of interests declared concerning the publication of this article.

Received: July 19, 2018.

Accepted: March 22, 2019.

The study was carried out at RiozOO foundation.

\section{*Correspondence}

Daniel de Almeida Balthazar

Instituto de Veterinária, Universidade Federal Rural do Rio de Janeiro - UFRR J

Rodovia BR 465, Km 7, Campus Universitário, Bairro Zona Rural

CEP 23897-000 - Seropédica (RJ), Brasil

E-mail: danielbalthazar@yahoo.com.br 
may be decreased or normal. When the thickness is normal, an increase in chamber size may indicate compensatory eccentric hypertrophy in an attempt to restore cardiac output. When wall thickness is decreased, and the chamber size is increased, this indicates dilation with severe loss of systolic function (Boon, 2011).

Most cases of DCM are due to primary or idiopathic causes (Tavares et al., 2016). This disease occurs after changes in myocardial cells, induced by inflammation, toxins, lack of essential cellular nutrients and/or genetic metabolic dysfunction (Ardila et al., 2009). Physiological hormonal changes, especially in females during the peripartum period (Avila et al., 2002; Pinto et al., 2007), and in cases of Chagas heart disease, have been identified as being a potential cause of dilated cardiomyopathy (Marin-Neto et al., 1999).

Dilated cardiomyopathy is considered a serious disease that causes several deleterious effects to the organism, caused by congestive heart failure and arrhythmias, increasing the mortality rate (Muzzi et al., 2000; Yancy et al., 2016). Its treatment involves the use of medications to control systolic dysfunction and the congestive process, with the aim of improving cardiac output (Borgarelli et al., 2001). However, this disease is progressive in nature, and life expectancy cannot be significantly extended (Tidholm et al., 2001).

The present work aims to report a case of dilated cardiomyopathy in a specimen of Ateles chamek (Humboldt, 1812), commonly known as spider monkey, housed in the Zoo of the city of Rio de Janeiro, focusing on clinical aspects, diagnosis and treatment, as well as the reversibility of the clinical and complementary findings after childbirth.

\section{Historical findings}

A young adult, female Ateles chamek who was pregnant, weighed $8 \mathrm{~kg}$, housed in the zoo of the city of Rio de Janeiro, in a collective enclosure with her family group, presented in the final third of gestation with edema in the vulva and perivulvar region, indicating possible signs of childbirth. After twenty days, the animal gave birth during the puerperal period, and the clinical signs of vulval edema and peri-vulvar region persisted, and a significant abdominal volume, apathy, and anorexia were reported.

At 30 days after delivery, the pup died, and 48 hours later, it was physically contained with puçá and sedated with ketamine hydrochloride $(10 \mathrm{mg} / \mathrm{kg})$ and midazolam $(1 \mathrm{mg} / \mathrm{kg})$ in order to remove the dead pup from the enclosure, perform clinical examinations, and transfer her to the veterinary hospital of RIOZOO Fundation.

After restraining, the hemogram was performed because it was the main screening test in captive animals, and for this reason was the first to be performed. This analysis found erythrocytopenia, indicating the presence of discrete anemia and an increase in the hematocrit value. The only abnormal finding on the serum biochemical tests was an elevated serum glucose. There were no pathological changes in hepatic or renal function. Serology and blood culture for Trypanosoma sp. were negative. On urinalysis, the only abnormal finding was an elevated glucose reading in the urine and all other values were within the normal range.

During the physical examination, hepatomegaly and increased abdominal volume were observed; we placed a 20-mL syringe puncture in the left flank and placed a needle 40x12mm in an attempt to collect ascites, but we were unsuccessful. We observed signs of dehydration with altered cutaneous turgor, normocorated mucosa; the pulsation values and capillary filling times were all within the normal range. Blood and urine were sent to the clinical pathology laboratory of the RIOZOO veterinary hospital. Vital parameters were assessed; the heart rate was 160 beats-per-minute and the respiratory rate was 45 breaths-per-minute.

The animal was referred for radiographic examination in the ventro-dorsal (Figure 1A) and right lateral (Figure1B) positions, where a marked increase of the cardiac silhouette was observed. Hepatomegaly was also confirmed, after being detected by palpation during physical examination.

After the exams, treatment with furosemide ( $4 \mathrm{mg} / \mathrm{kg}$ ), twice-daily was administered orally. On the ninth day of treatment, digoxin $(0,005 \mathrm{mg} / \mathrm{kg})$ was added at a dose administered orally twice-daily with milk.

On the 18th day of treatment, the animal was submitted to a new physical restraint, with puçá and was taken to the chemical containment, according to the previously mentioned protocol. Anesthesia was induced using isoflurane with an anesthetic mask. Clinical, electrocardiographic, 


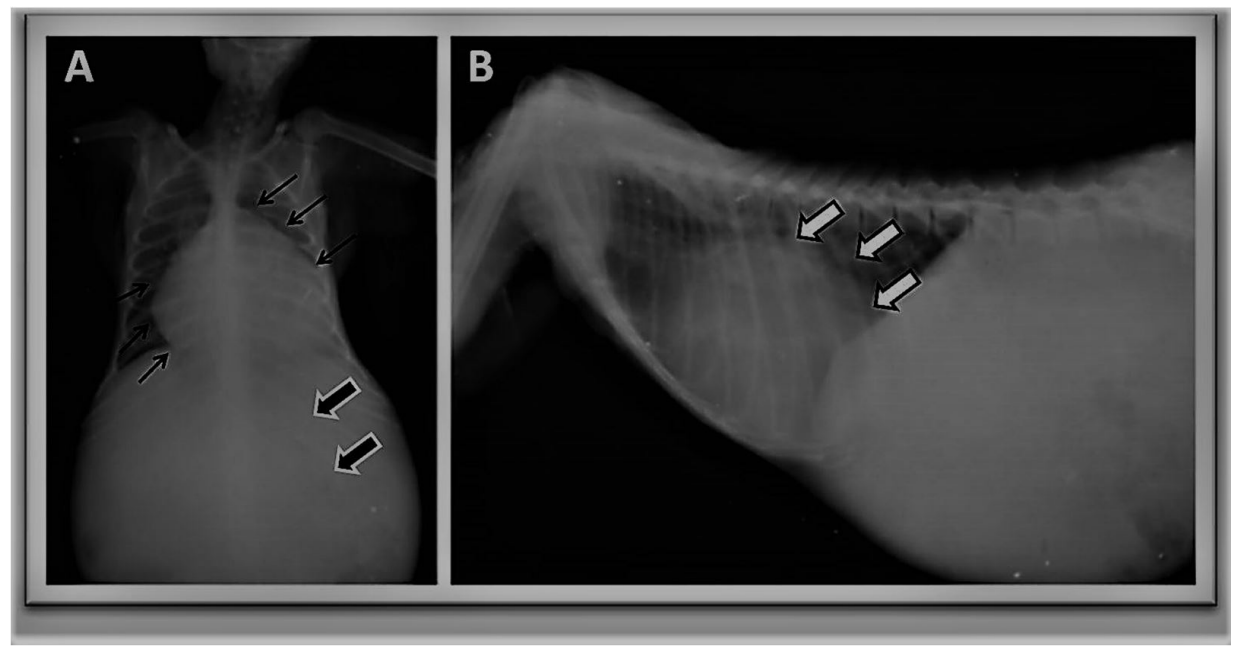

Figure 1. (A) Radiographic examination, in a ventro-dorsal position, evidencing increased cardiac silhouette (fine arrows) and marked abdominal volume (arrow outline); (B) Radiographic examination, in a right lateral position, evidencing an increase in the cardiac silhouette (filled arrow).

and echocardiographic examinations were performed. At the clinical examination, the mean heart rate was 140 beats-per-minute, respiratory rate between 40-50 movements per minute, pulmonary auscultation without alterations, galactic heart auscultation, and systolic murmur in mitral and tricuspid focus, as well as hypokinetic pulse. The electrocardiographic tracing revealed sinus rhythm, with preserved cardiac axis and suggestive left atrial overload.

Echocardiographic examination revealed an ejection fraction of 37\% (Ref.: 55-75\%) and decreased shortening fraction of 16\% (Ref.: 35-45\%), indicating a below-normal value compared to human primates (Elliott, 2000), dogs and cats (Boon, 2011). Other evidence was eccentric hypertrophy of cardiac chambers already evolving for dilatation, being more accentuated in right chambers, slight decrease of free walls and interventricular septum, and deficit of systolic function, with hypokinetic muscles (Figures 2 and 3).

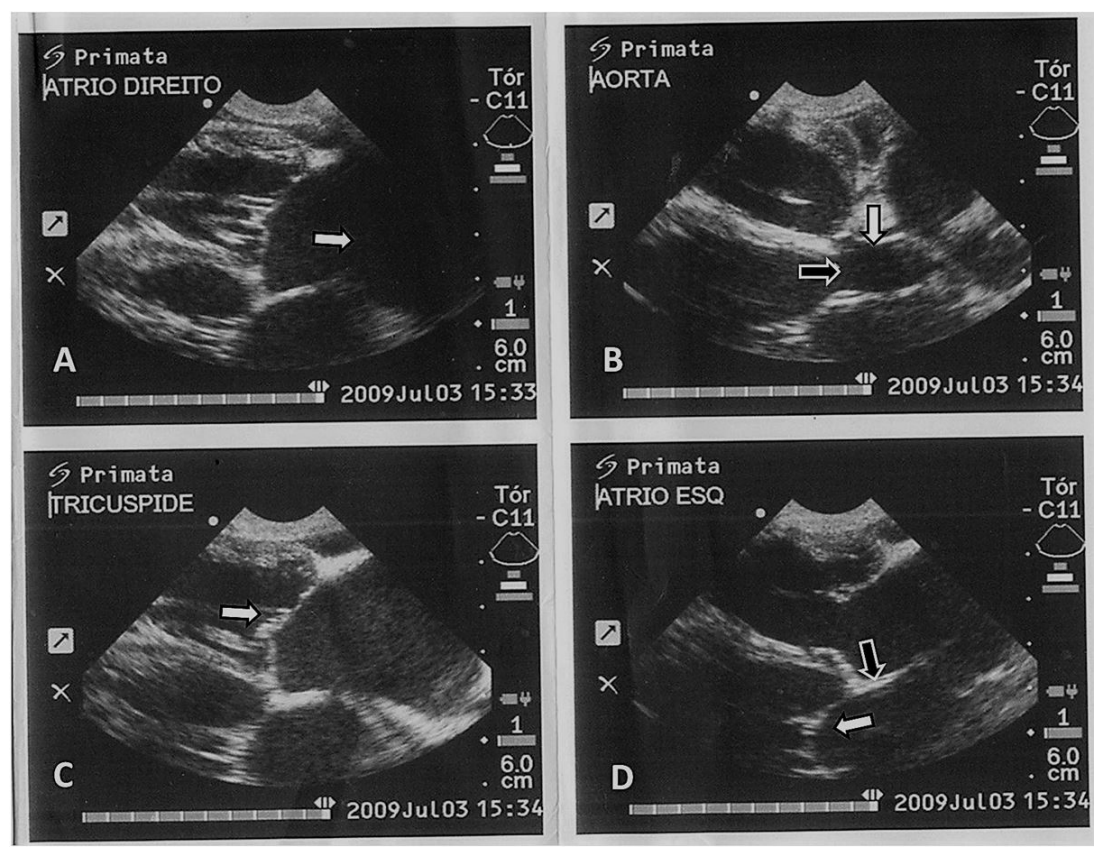

Figure 2. Echocardiographic examination. (A) Enhanced right atrium (filled arrow); (B) Aorta unchanged: preserved aortic valve (arrow outline) and intact aortic entry (filled arrow); (C) Discrete reflux in tricuspid, evaluated by Doppler (filled arrow); (D) Left atrium with overload and eccentric hypertrophy (arrow outline), mitral valve with discrete thickening (filled arrows). Results compared to established reference values for dog. 


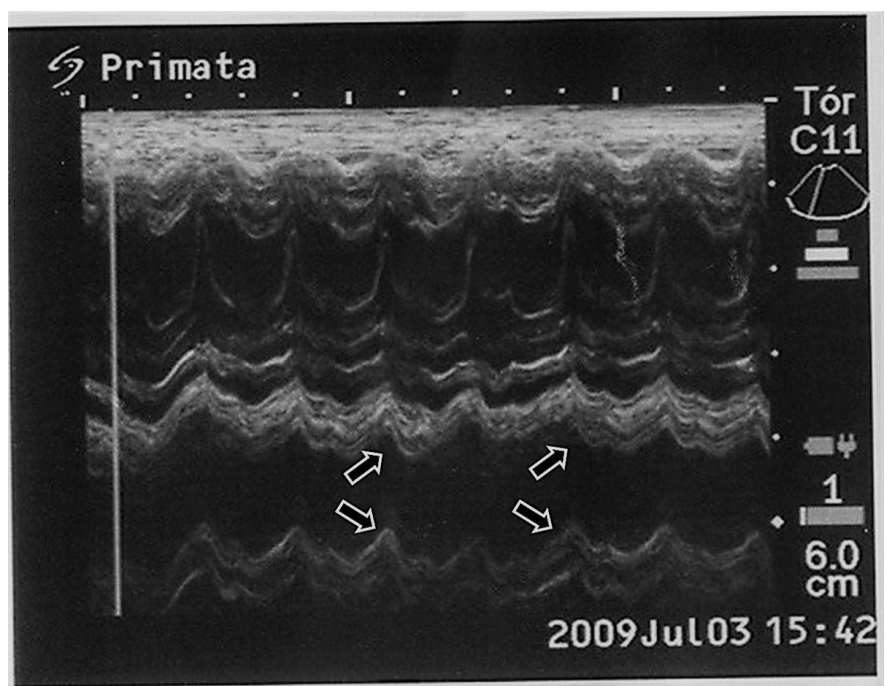

Figure 3. Echocardiographic examination in two-dimensional mode, indicating low shortening fraction (arrow outlines), and consequent reduction in systolic function. Results compared to established reference values for dog.

After the exams, another drug was added to the treatment: enalapril $(0,5 \mathrm{mg} / \mathrm{kg})$, which was administered orally every 12 hours with milk. After 30 days of treatment, the animal presented with clinical improvements, demonstrating a decrease in vulvar edema and perivulvar region, a reduction of abdominal volume, and an improvement in physical disposition.

Around the 90th day of treatment, the animal underwent a new clinical examination. The liver size was within the normal range, there was a reduction in the abdominal volume and a satisfactory physical state was observed. A radiographic examination was performed in the ventro-dorsal (Figure 4A) and right-lateral (Figure 4B) positions. The cardiac silhouette resembled the expected patterns in healthy neotropical primates.

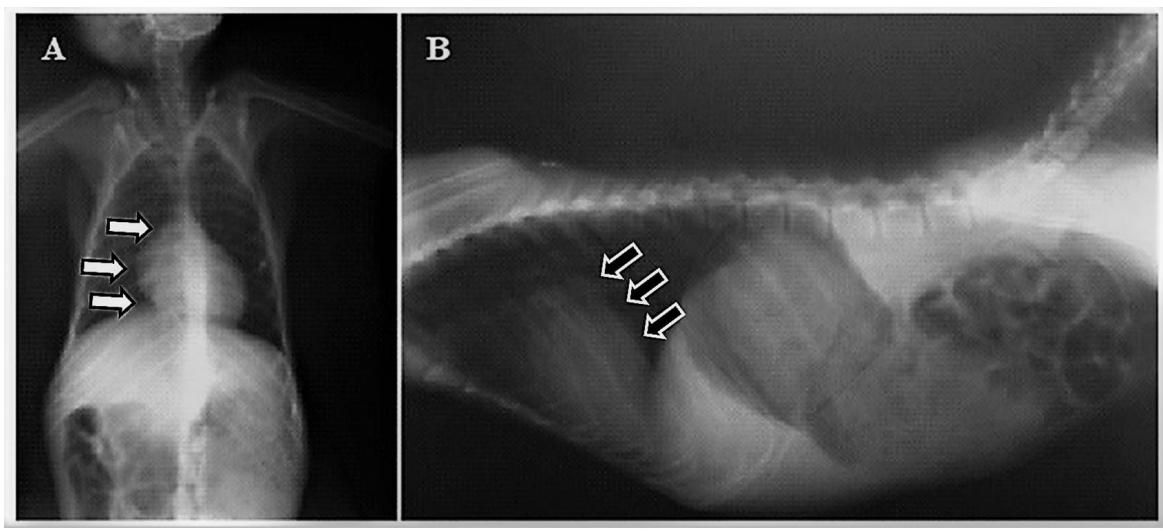

Figure 4. (A) Radiographic image in ventro-dorsal position, evidencing remission of cardiomegaly during the treatment (filled arrows); (B) Radiographic image in a right lateral position, evidencing remission of remodeling of the cardiac silhouette (arrow outlines).

As a result of this radiographic assessment, the use of furosemide was maintained, and all other medications were discontinued.

\section{Discussion}

Primates of the genus Ateles usually live in family groups, in which they organize themselves in search of food. The pup is carried by the mother, but the whole group assists in caring for it (Youlatos, 2002; Wallace, 2005). The female of the present report was not withdrawn from family 
life, even with the persistence of vulvar edema and perivulvar edema due to the involvement of the other members of the family with the newborn and their interaction within their social environment.

It is probable that the puppy died due to the female's debilitated state, decreased or interrupted lactation and/or involuntary carelessness with the newborn. The female was physically restrained and sedated to remove the dead pup, since primates tend to remain with the pup's body sometimes until it is already in an advanced state of decomposition (Verona \& Pissinatti, 2014). The purpose of the procedure was also to perform tests to evaluate the general health and diagnosis of the cause of abdominal volume increase.

Erythrocytopenia, indicating the presence of discrete anemia with increased hematocrit value, may be related to dehydration, compatible with the patient's clinic (Kindlovits \& Kindlovits, 2009).

High glycemic values, as well as glycosuria, are related to hepatic alterations or renal glycosuria, as well as the correlation of possible gestational diabetes (Tidholm et al., 2001).

At physical examination, abdominal palpation with detection of hepatomegaly may indicate venous congestion, since this signal occurs by blood stasis in the return pathway and characterizes edema and effusion formations (Borgarelli et al., 2001).

According to Schelling (2002), for cardiac evaluation using the radiographic examination, the dorso-ventral position should be preferred in relation to the ventro-dorsal position, due to the positioning of the heart. In this report, radiographic examination was performed in the ventro-dorsal position, since it occurred before the suspicion of cardiomyopathy and, in the same way, the cardiac remodeling was evidenced.

Cardiac auscultation demonstrated a gallop rhythm, which may indicate early heart failure and is compatible with the clinical suspicion of dilated cardiomyopathy (Charlier, 2016). The gallop rhythm is characterized by the presence of pathological S3 and S4 sounds, which has its origins in the presence of eccentric hypertrophy and atrial dilatation, respectively (Atkins, 1999).

In the electrocardiographic tracing, no disturbances of the heart rhythm were observed, which, may occur in more advanced cases, such as tachyarrhythmias and atrial fibrillation (Calvert, 2002).

On echocardiographic examination, the results were compatible with clinical suspicion, with ejection fraction indicating below normal values compared to human primates (Elliott, 2000), dogs and cat (Boon, 2011). Another finding is the reduced shortening fraction (16\% Ref.: 35-45\%), also compared to human primates, indicating a reduction in the force of myocardial contraction, characteristic of dilated cardiomyopathy (Borgarelli et al., 2001). There is no established reference for the species cited in the report, both for ejection force and shortening fraction, although during the qualitative evaluation, a clear reduction of the evaluated parameters was evidenced.

The therapy instituted in the present case was determined according to clinical evolution and as the complementary tests were performed, the results were found to be associated with dilated cardiomyopathy (Wojnowich \& Korabathina, 2016). Diuretic use was prescribed because of congestive heart failure, severe cardiac remodeling, and effusions. The use of digoxin, a moderate positive inotropic action drug that reduces sympathetic activity in the insufficient heart, was added with the objective of improving cardiac output and increased contraction force on heart muscle (Morris et al., 2006). The use of enalapril, an angiotensin converting enzyme inhibitor, has been added to promote arterial and venous vasodilation, and to attenuate the congestive process. Thus, the triad of congestive heart failure was improved: inotropism, vasodilation, and decreased effusions and/or edema formation (Yancy et al., 2016).

According to Tidholm et al. (2001), dilated cardiomyopathy has unknown etiology in dogs, so there are several factors to explain the causes of the disease: family, genetic, nutritional factors, and metabolic disorders. Usually dilated cardiomyopathy in humans has an idiopathic cause, but there are reports of the occurrence of the disease in women in peri-parto period (Oliveira et al., 2012). In non-human primates, the etiology of dilated cardiomyopathy remain unknown.

The spider monkey female was in the peri-parturition period when it was evidenced and there were persistent clinical signs in the puerperal period. Peri-parturition dilated cardiomyopathy is a rare disease, related to the gestational and puerperium period, probably due to the changes that occur in the organism (Yancy et al., 2016). 
Ávila and and collaborators cite as differential diagnosis for the presented picture, heart failure in the final third of gestation or immediately after delivery, and may persist for subsequent months, as occurred in the sample of the present report.

In addition, systolic dysfunction demonstrated by reduction of ejection fraction and left ventricular shortening fraction verified in echocardiographic examination, also performed in the female, is also evidenced, being factors with strong indicative for the presentation of this disease, in the case in question, in the absence of other clinical or echocardiographic findings (Charlier, 2016).

However, a disease with a degree of advanced cardiac remodeling with an installed process of congestive heart failure does not have descriptions of remission of clinical and radiographic findings such as the one presented, bringing the importance of studies that may describe possible new cases and relate to a cause which is yet unexplained, in regard to human medicine.

\section{Conclusion}

In the present report, it was possible to conclude the occurrence of dilated cardiomyopathy in a specimen of Ateles chamek, popularly known as spider monkey, demonstrating the atypical course that the disease develops, by comparing to cases in human primates and neotropical primates.

The disease was related to the peri-parturition period due to the hormonal and metabolic changes that occurred and also to the physiological interactions of gestation and puerperium in the organism.

Clinical treatment proved to be effective during the therapeutic protocol. In general, with the treatment instituted, the animal was able to present reduction in the cardiac perimeter and area, clinical signs were improved, and the survival was improved, but remission of clinical and complementary findings was difficult to prevent due to the disease progression.

It is strongly suggested that the inducing factor of cardiac alterations, as well as heart failure, was in fact excluded from the evolution achieved, ratifying the organic influences that the gestational and postpartum period can bring.

\section{Acknowledgements}

We thank the RioZOO Foundation for all support.

\section{References}

Ardila, D. F. P., Hurtado S. N., Osorio E. M. A., \& Rosero R. A. A. (2009). Miocardiopatía periparto. Insuficiencia Cardiaca, 4(4), 177-183.

Atkins, C. E. (1999). Cardiac manifestations of systemic and metabolic disease. In P. P. Fox, D. Sisson, \& N. S. Moise (Eds.), Textbook of canine and feline cardiology: principles and clinical practice (2nd ed., pp. 757-780). Philadelphia: WB Saunders.

Avila, W. S., Carvalho, M. E. C., Tschaen, C. K., Rossi, E. G., Grinberg, M., Mady, C., \& Ramires, J. A. F. (2002). Gravidez em portadoras de cardiomiopatia dilatada periparto: estudo prospectivo e comparativo. Arquivos Brasileiros de Cardiologia, 79(5), 484-488. PMid:12447499.

Boon, J. A. (2011). Myocardial diseases. In J. A. Boon (Ed.), Veterinary echocardiography (2nd ed., pp. 359-410). Hoboken: Wiley-Blackwell.

Borgarelli, M., Tarducci, A., Tidholm, A., \& Häggström, J. (2001). Canine idiopathic dilated cardiomyopathy - part II: pathophysiology and therapy. Veterinary Journal (London, England : 1997), 162(3), 182-195. http://dx.doi. org/10.1053/tvjl.2001.0616. PMid:11681869.

Calvert, C. A. (2002). Cardiomiopatia canina. In Tilley L. P., \& J. K. Goodwin (Eds.), Manual de cardiologia para cães e gatos (3. ed., pp. 133-152). São Paulo: Roca.

Charlier, M. G. S. (2016). Avaliação da função cardíaca de bugio ruivo (Alouatta Guariba Clamitans) em cativeiro (Dissertação de mestrado). Universidade Estadual Paulista "Júlio de Mesquita Filho", Botucatu.

Elliott, P. (2000). Diagnosis and management of dilated cardiomyopathy. Heart (British Cardiac Society), 84(1), 106-112. http://dx.doi.org/10.1136/heart.84.1.106. PMid:10862601.

Kindlovits, A., \& Kindlovits, L. M. (2009). Clínica e terapêutica em primatas neotropicais (2. ed., 535 p.). Rio de Janeiro: L. F. Livros.

Lobo, L. L., \& Pereira, R. (2002). Cardiomiopatia dilatada canina. Revista Portuguesa de Ciências Veterinárias, 97(544), 153-159. 
Marin-Neto, J. A., Simões, M. V., \& Sarabanda, A. V. L. (1999). Cardiopatia chagásica. Arquivos Brasileiros de Cardiologia, 72(3), 247-263. PMid:10513039.

Morris, S. A., Hatcher, H. F., \& Reddy, D. K. (2006). Digoxin therapy for heart failure: an update. American Family Physician, 74(4), 613-618. PMid:16939183.

Muzzi, R. A. L., Muzzi, L. A. L., Pena, J. L. B., \& Nogueira, R. B. (2000). Cardiomiopatia dilatada em cão - relato de caso. Ciência Rural, 30(2), 355-358. http://dx.doi.org/10.1590/50103-84782000000200027.

Oliveira, F. T. M., Oliveira, G. C. R., Meira, M. L. G., Mendes, M. M., Amaral, M. S. G., Costa, P. R. S. M., Versiani, P. V., Ribeiro, P. M. G., \& Krettli, W. S. C. (2012). Cardiomiopatia periparto. Revista Médica de Minas Gerais, 22(Supl 5), S25-S27.

Pinto, C. G., Colaço, J., Maya, M., Avillez, T., Casal, E., \& Hermida, M. (2007). Miocardiopatia periparto. Acta Medica Portuguesa, 20, 447-452.

Schelling, C. G. (2002). Exame radiográfico do coração. In L. P. Tilley, \& J. K. Goodwin (Eds.), Manual de cardiologia para cães e gatos (3. ed., pp. 15-38). São Paulo: Roca.

Tavares, A. C., Bocchi, E. A., \& Guimarães, G. V. (2016). Functional class in children with idiopathic dilated cardiomyopathy: a pilot study. Arquivos Brasileiros de Cardiologia, 106(6), 502-509. http://dx.doi.org/10.5935/ abc.20160066. PMid:27168472.

Tidholm, A., Häggström, J., Borgarelli, M., \& Tarducci, A. (2001). Canine idiopathic dilated cardiomyopathy - part I: etiology, clinical characteristics, epidemiology and pathology. The VeterinaryJournal.,162(2), 92-107. http:// dx.doi.org/10.1053/tvjl.2001.0571. PMid:11531394.

Verona, C. E. S., \& Pissinatti, A. (2014). Primates - primatas do novo mundo (sagui, macaco-prego, macaco-aranha, bugio e muriqui). In Z. S. Cubas, J. C. R. Silva \& J. L. Catão-Dias (Eds.), Tratado de animais selvagens ( $2^{\text {nd }}$ ed., pp. 723-743). São Paulo: Roca.

Wallace, R. B. (2005). Seasonal variations in diet and foraging behavior of Ateleschamek in a southern amazonian tropical forest. International Journal of Primatology, 26(5), 1053-1075. http://dx.doi.org/10.1007/s10764-005-6458-4.

Wojnowich, K., \& Korabathina, R. (2016). Heart failure update: outpatient management. FP Essentials, 442, 18-25. PMid:26974001.

Yancy, C. W., Jessup, M., Bozkurt, B., Butler, J., Casey Junior, D. E., Colvin, M. M., Drazner, M. H., Filippatos, G., Fonarow, G. C., Givertz, M. M., Hollenberg, S. M., Lindenfeld, J. A., Masoudi, F. A., McBride, P. E., Peterson, P. N., Stevenson, L. W., \& Westlake, C. (2016). 2016 ACC/AHA/HFSA focused update on new pharmacological therapy for heart failure: an update of the 2013 ACCF/AHA guideline for the management of heart failure: a report of the American College of Cardiology Foundation/American Heart Association Task Force on Clinical Practice Guidelines and the Heart Failure Society of America. Circulation, 134(13), 282-293. PMid:27208050.

Youlatos, D. (2002). Positional behavior of black spider monkeys (Ateles paniscus) in French Guiana. International Journal of Primatology, 23(5), 1071-1093. http://dx.doi.org/10.1023/A:1019602116805. 